\title{
Exploratory and Confirmatory Factor Analysis on the Values Aspects of Teacher Leadership Model
}

\author{
Hamidah Yusof*, Nor Hasimah Ramelan, Mohd Asri Mohd Noor, Mahaliza Mansor \\ Faculty of Management and Economics, Universiti Pendidikan Sultan Idris, Malaysia
}

Received September 22, 2020; Revised November 2, 2020; Accepted November 8, 2020

\section{Cite This Paper in the following Citation Styles}

(a): [1] Hamidah Yusof, Nor Hasimah Ramelan, Mohd Asri Mohd Noor, Mahaliza Mansor, "Exploratory and Confirmatory Factor Analysis on the Values Aspects of Teacher Leadership Model" Universal Journal of Educational Research, Vol. 8, No. 12, pp. 7085 - 7100, 2020. DOI: 10.13189/ujer.2020.081276.

(b): Hamidah Yusof, Nor Hasimah Ramelan, Mohd Asri Mohd Noor, Mahaliza Mansor (2020). Exploratory and Confirmatory Factor Analysis on the Values Aspects of Teacher Leadership Model. Universal Journal of Educational Research, 8(12), 7085 - 7100. DOI: 10.13189/ujer.2020.081276.

Copyright $\bigcirc 2020$ by authors, all rights reserved. Authors agree that this article remains permanently open access under the terms of the Creative Commons Attribution License 4.0 International License

\begin{abstract}
Teacher leadership is gaining momentum in the school improvement program nowadays. School reformation depends on teacher leaders' ability to implement new approaches and help colleagues develop their skills, values, and expertise. Thus, this study aimed to develop and validate the teacher leadership instrument to measure the aspect of value using Exploratory Factor Analysis (EFA) and Confirmatory Factor Analysis (CFA), which has 31 items. The data were analyzed using Statistical Packages for the Social sciences version 22 and Structural Equation Modelling version 20.0. This study was administered to 320 teachers in 19 secondary schools in Kuala Lumpur, Malaysia, using questionnaires. The Exploratory Factor Analysis (EFA) yielded a 29 items three-factor model termed as Being a Consultant (PR), Fostering a Cooperation Culture (MBK), and Leading the Teaching and Learning Process (PPdP). The Confirmatory Factor Analysis yielded 17 items demonstrating three factors that achieved the model fit index, with Chi-squared/degree of freedom (Chisq/df) $=2.541$, Tucker-Lewis Index $(\mathrm{TLI})=0.934$, Comparative Fit Index $(\mathrm{CFI})=0.944$; and Root Mean Square Error of Approximation (RMSEA) $=0.070$. The composite reliability and average variance extracted of the domains ranged from 0.54 to 0.57 and 0.85 to 0.89 . The study found that the instrument is valid and reliable in measuring the values aspect of teacher leadership models. This model's development can have a huge impact on teachers' leadership training through the teachers' professionalism improvement programs.
\end{abstract}

Keywords Teacher Leadership Values, Teaching and Learning, Cooperative Culture, Teacher as a Consultant

\section{Introduction}

Teachers act as the core in determining the success of the implementation of the national curriculum. Educators or teachers are not only responsible for delivering knowledge to their students, but they are also responsible for making sure their students have good manners [1]. Teachers with positive self-values can influence the school's teaching and learning environment and make a significant impact on students' learning process [2]. These farsighted, virtuous, and positive thinking teachers will improve the students' quality and increase school performance at the same time [3]. Moreover, the teachers' adhering to the code of ethics as educators and decent manners will make them carry out their responsibility as educators with dedication [4].

Teachers with higher cognitive skills and excellent personality will be great role models for them [5]. Teachers are also an essential agent of change in developing individuals' physical, intellectual, emotional, and social potential [6]. Hence, teachers with low self-esteem will have a lower motivation to carry out their entrusted responsibilities. To overcome these problems, teachers must have substantial values and identity within themselves. According to Zakaria et al. [6], teachers should practice and appreciate values first before educating the 
children. This finding is in line with the statement made by Lickona [7] that described teachers as role models in values. They must act as guardians, models, and mentors to the students. They also need to create a moral community, practice the righteous discipline, build a democracy class, teach values across the curriculum, use cooperative learning, build conscience of craft, foster concern beyond the classroom, and build a positive culture in the school cooperated with the parents.

Teachers need to have leadership values such as excellent personal characteristics, perfect stature, and special characters in conveying general knowledge and ethical character education [8]. A study by Nik Aziz [9] mentioned that teachers must have an excellent moral, intellectual, emotional, creativity, motivation to teach, mentoring skills, and outstanding leadership skills in the classroom to make the learning process more effective. According to a study by Apidah [10], teachers play a vital role in educating and shaping student's morals and values. Gamal [11] explained that because teachers' behaviors are always observable, they should show excellent behavior to their students and their colleagues. They also must equip themselves with essential knowledge and noble characters to their students. Thus, teachers with exceptional leadership values can carry out their duties as educators successfully [12].

Lambert et al. [13] stated the new teachers lack awareness, skills, knowledge, and values to become teacher leaders. According to Johnson [14], long serviced teachers always gave excuses for the lack of exposure to teacher leadership skills in teachers' training college to fulfil their respected responsibilities. This assertion is supported by Dozier [15], who did a survey on teacher leaders in Virginia and found that $82 \%$ of the respondents said that they did not undergo any training on teacher leadership in teachers' training institutions. Bond [16] stated that the teacher leader must start from the future teachers who are still undergoing teachers' training at the college. A recent study by Huggins et al. [17] found that teachers failed to see themselves as leaders in the community. Most of them said that they did not receive proper training in teacher leadership; therefore, they did not have a clear understanding of what teacher leadership entailed and unsure of the impact of a better leader, which will make them better teachers.

Wenner [18] stated that a study in teacher leadership is still scarce in the literature. There is no comprehensive review in this scope; even there is a tremendous change in policy and other influences resulting in educational changes. Study about teacher leadership focused on narrow aspects of the field. Although teacher leadership is viewed as a crucial component in the success of teaching and learning [19], there is little literature on teacher leadership development [20]. There are not many studies that are explicitly done on teacher leadership values, either locally or abroad. Mostly all the previous studies focused only on the principals or administrators.

The teacher leadership field's research enhanced the Ministry of Malaysia Education's insistence to produce more professional teachers who have better qualities, higher self-values, more knowledgeable, and have excellent skills. This effort is necessary because education is the instrument for processing, forming, nurturing, encouraging, building, and shaping the younger generation's face that can contribute to their country [21]. The continually changing system in Malaysian education increases the teacher's workloads, and therefore, it can demotivate teachers to perform. In recent years, too many crises involving teachers have become the national agenda. Indirectly, the issues and problems that arise have affected the teaching profession itself. The teachers faced criticism from the public, such as the leakage of 2014's Ujian Pencapaian Sekolah Rendah (UPSR) question paper. The crowd began to question the integrity of the teachers [22]. This situation is preventable if teachers have high integrity towards their profession. Therefore, this study aimed to develop a teacher's leadership value model that can be applied to the existing model of teacher's leadership. This added value can be served as guidance to teachers worldwide, especially in Malaysia, to practice these values in the classroom.

\section{Literature Review}

The definition of teacher leadership is very complex [23]. York-Barr and Duke [24] defined teacher leadership as a process where experienced teachers will influence their colleagues and other members in the school society, improve the way students learn, and improve the teaching methodology in the classroom. Katzenmeyer and Moller [25] defined teacher leadership as a teacher who leads within and beyond the school, contribute to a community of teachers-learners and leaders, and influence other teachers to improve their educational practice. Most researchers agree that teaching and learning will improve these leadership skills, create a better school environment, and increase professionalism in the teacher's profession [26].

Teacher leadership is a tool to support school-wide improvement [24],[27],[28]. Teachers must have commendable attitudes to lead the students to become better human beings. According to Ismail [29], the teachers' personal quality is essential as the teachers are the source to be emulated in the construction of moral values. Although various efforts made to define teacher leadership and diverse literature supported the concept of teacher leadership as a central focus in the school improvement program, Helterbran [30] and Brennerman [31] stated that this message had not reached every teacher widely. Therefore, the Ministry of Education 
Malaysia had made an effort to enlist six core values that must be followed by every teacher.

The six core values enlisted by the Ministry of Education Malaysia are trustworthy, diligent, thinking, caring, knowledgeable, and virtuous [22]. In comparison, there are seven core values in MOE's working ethics: trust, discreet, dedicated, loving, truthful, thankful, and sincere. The guidelines of these values should be implemented and internalized based on the five principles of working ethics of teaching, namely having the right intentions, good manners, driving towards the good, keeping up the words, disciplined and civilized. These values will make teachers behave, think, and act appropriately [32].

Therefore, in this study, teachers value refers to the positive personal traits showed by the teachers either directly or indirectly. These teacher leadership values also refer to the teachers' characteristics to influence others informally to achieve their goals. There are six proposed earlier constructs to represent teacher leadership values in the Malaysian context which are Leading Teaching and Learning Process (PPdP), Being A Follower (MI), Involving Actively in The Organization (KAdO), and Fostering Cultural Cooperation (MBK), Connecting to The Community (JK) and Being A Consultant (PR). The constructs are developed based on the Rokeach Theory [33], the Theory of Schwartz [34], The Twelve Pillars [35], and Malaysian Teachers' Standard [36].

\subsection{Leading Teaching and Learning Process (PPdP)}

In this dimension, the teacher acts as a leader in the teaching and learning process. It refers to the teacher's primary responsibilities to educate the students. The teachers educate the students by imparting knowledge to them and emphasizing the students' personality and moral development. Therefore, the teachers' behaviors as a role model to the students are critical [4]. Teachers should always discard their selfishness and prioritize the students' interests and welfare [37]. According to Zenger and Folkman [38], teacher leaders must be humble and honest in building positive relationships between teachers and students.

Teachers need to plan earlier before execute the teaching and learning activities. This prior planning will ensure the students will benefit more in the teaching and learning sessions. It will serve as a guide to the teacher's reaction in the classroom. According to Macnab and Payne [39], teachers' attitudes in the classroom will strongly influence classroom practices. Therefore, teachers' values are crucial as they will guide the teachers to understand the responsibilities they have to fulfil in the classroom. This construct showed that teachers act as a facilitator in the classroom and as the person who can bring changes to the student's life. These changes do not only happen in the classroom but also around the school environment and society. This sub-construct coincides with the six core values listed by Schwartz [34] and Rokeach [33], which describes the instrumental values.

\subsection{Being a Follower (MI)}

The dimension Being a follower (MI) in this study refers to the teachers' attitudes and behaviors directed by the people around them. Teachers' behaviors always show the values of open-minded, respect others' views, and often exhibit confidence and assertiveness [40]. These behaviors make them fit as a teacher leader. Moreover, teacher leaders must have a flexible attitude, be willing to try different approaches to solving problems, be bold enough to take risks and be role models to the students [41].

Teacher leaders also showed excellent leadership values and ethics to develop students' skills, train them to be more creative and innovative, adept in decision-making, and motivate them to excel [42]. Teachers who always show mutual respect to their colleagues and students had a high possibility of serving and loving the students, having more resilience and motivation to produce better students [16]. Therefore, being a follower or able to influence others is an essential process in teacher leadership. As described earlier, the teacher leaders who have good and positive values will quickly affect the students and colleagues to meet the specified goal, especially in strengthening the organization [43].

\subsection{Involving Actively in the Organisation (KAdO)}

In this dimension, the teachers' active involvement in the organization means the teacher's behaviors to carry out their responsibilities in the organization. These behaviors include the teachers who are brave enough to face the challenges, independent of carrying out their duties, and able to guide their colleagues towards excellence [44]. In a study on Teacher Leadership, Collective Efficacy and Trust in School by Angelle, Nixon, Norton, and Niles [45] found that teacher leaders have a significant impact on the organization's development as it goes beyond the role and responsibility of an individual teacher.

A study by Hope-Arlene [46] listed several things that can be practised by the teachers which are; i) involving in the decision making and leadership at the school; ii) discussing the planning on the school improvement, iii) focusing on professional development, iv) providing a space for the teachers to develop their talents, v) having an excellent communicating skills and vi) being able to collaborate with other teachers. Whereas, Suranna and Moss [47] identified the leadership characteristics that should be owned by every teacher leader, namely; involved in the process of professional development; increase professional knowledge sharing; have their stand 
on education issues, and act as a facilitator. Through these opportunities, teachers should be bold to face challenges and overcome the weaknesses in themselves. Therefore, these opportunities must have strong support from the principals and headmasters to ensure that teachers are equipped with all these qualities.

\subsection{Fostering a Cooperation Culture (MBK)}

Fostering a collaborative culture in this study refers to the teachers' dedication and commitment to carrying out their duties in collaboration with other teachers. The teachers who have these values are often interested in their works, willing to sacrifice their time and efforts to deliver high-quality works, and also willing to help and guide their colleagues, especially the newcomers [47]. They will also be willing to share their knowledge, skills, and techniques in the teaching and learning process and have a high awareness of the latest development in education. These behaviors will indirectly raise the teacher's confidence in carrying out their entrusted task [48].

A study by Dahlgren and Chiriac [49] found that teachers admitted that their job requires them to work as a team. Gregory [50] stressed that the difference in teacher learning outcomes is caused by the teachers' negative or positive responses against their team members. Thus, the culture of cooperation or teamwork affects their learning ability. The strong influence on learning in the organization came when teachers were committed to carrying out their group dynamics [51].

The leadership values involved in the cooperation culture among the colleagues can be influenced by sharing the expertise in teaching [52]. It can be done formally in the classroom or informally interacting with fellow teachers during their free time [53]. The activities that can be carried out, such as establishing professional learning, guidance from colleagues, as well as cooperation and support from a more extensive and comprehensive learning community. This leadership value, which fosters a cooperative culture, is essential to support new teachers in improving their teaching and learning strategies.

\subsection{Connecting to the Community (JK)}

Connecting to the community in this study refers to the teachers' accountability when working with their colleagues. Teachers must establish an honest and persistent relationship with the parents, community, and other stakeholders to improve the education system and expand students' learning (SGM). This dimension is in line with one of the domains in Teacher Leader Model Standards [54]: to improve the relationship and cooperation with the families and communities. Teacher leaders demanded to understand the student's family condition, society, and the culture around them. This understanding will significantly impact the students' learning environment and indirectly improve educational processes. At the same time, teachers must realize that they need to have accountability towards the students, parents, colleagues, community, and as well as to the nation.

\subsection{Being a Consultant (PR)}

Being a consultant is referred to the teacher's prominent role, which is to guide the students to achieve an excellent achievement either in academics or curricular activities. Teachers also demanded to lead the students and colleagues in achieving their goals without any instruction or coercion. The high-value in teacher's integrity can produce leaders capable of leading the process of change in education based on each other's religions and beliefs [55],[56]. In conclusion, teachers with higher integrity values can become leaders who could be referred by the students, colleagues, parents, and community. Thus, this dimension provides opportunities for experienced teachers to share their expertise with the new teachers [57] to improve teaching quality.

\section{Methods}

\subsection{Design}

This study is a quantitative research that used a descriptive survey design. Confirmatory factor analysis (CFA) performed on the 31 items version of the teacher leadership model measuring the value aspects. Confirmatory factor analysis is a multivariate statistical technique used mostly in social science research [58]. This approach is frequently used to test the construct validity and dimensionality of the development scale or instruments. Thus, it is appropriate to test the number of factors or the latent constructs that will best fit the model examined.

\subsection{Participants}

The respondents consist of 320 teachers selected randomly from 19 secondary schools around Kuala Lumpur, Malaysia. A total of 239 (74.7\%) female teachers and $81(25.3 \%)$ male teachers have participated in this study. As a sample is more significant than 200, it meets the rule of thumb mentioned by Hair et al. [58], [59] to decrease the likelihood of problems on the model's degree of freedom.

\subsection{Instrumentation}

In this study, the researcher used a set of a questionnaire containing 31 items (questions). The construct of Leading Teaching and Learning Process 
(PPdP) consisted of six items, Being A Follower (MI) with five items, Involving Actively in The Organization (KAdO) with four items, and Fostering Cultural Cooperation (MBK) with six items, Connecting to The Community (JK) with six items and Being A Consultant (PR) consisted of four items. All the research instruments were adapted from the Teacher Leadership Instrument built by the Universiti Pendidikan Sultan Idris (UPSI) researchers under Niche-Research Grant Scheme (NRGS) 2014. The content validity, which was done by the experts in leadership, had a score between 0.72 and 0.92 . It was acceptable, according to Tuckman and Waheed [60].

\subsection{Data Analysis}

\subsubsection{Exploratory Factor Analysis (EFA)}

The EFA was conducted on all six sub-constructs containing 31 items. Table 1 showed the initial constructs and items before the EFA conducted. A total of 100 questionnaire instruments were administered to teachers currently pursuing a Master of Education Management course at Sultan Idris Education University. EFA analysis was performed using the 'principal component analysis' (PCA) method. It is conducted to identify the underlying factors in the instruments [61]. Based on this method, items with a low value of less than or equal to 0.5 are dropped [58], [59].

Table 1. The initial constructs and items before EFA conducted.

\begin{tabular}{|c|c|c|}
\hline Code & Constructs & Item \\
\hline NIL1 & \multirow{6}{*}{$\begin{array}{l}\text { Leading Teaching and Learning } \\
\text { Process (PPdP) }\end{array}$} & Adhere to a comprehensive philosophy of national education \\
\hline NIL2 & & exhibit a variety of leadership values and behaviors \\
\hline NIL3 & & learn from their own experience \\
\hline NIL4 & & have a high commitment to fulfil students need \\
\hline NIL5 & & adopt a culture of cooperation to maximize student performance \\
\hline NIL6 & & exhibit sensitivity to the diversity that exists in the classroom \\
\hline NIL7 & \multirow{5}{*}{ Being A Follower (MI) } & $\begin{array}{l}\text { honest and humble in the effort to build positive interactions with fellow teachers and } \\
\text { students }\end{array}$ \\
\hline NIL8 & & adopt a culture of creativity and innovation \\
\hline NIL9 & & able to apply ethics/integrity in leadership practices \\
\hline NIL10 & & have a high commitment to meet students need \\
\hline NIL11 & & creative in fostering good decision-making skills among friends and students \\
\hline NIL12 & \multirow{4}{*}{$\begin{array}{l}\text { Involving Actively in The } \\
\text { Organization (KAdO) }\end{array}$} & willing to take risks to achieve educational goals \\
\hline NIL13 & & ready to face challenges to achieve educational goals \\
\hline NIL14 & & have the value of lifelong learning \\
\hline NIL15 & & successfully encourages students and colleagues to achieve excellence \\
\hline NIL16 & \multirow{6}{*}{$\begin{array}{l}\text { Fostering Cultural Cooperation } \\
\qquad(\mathrm{MBK})\end{array}$} & able to cultivate teamwork spirit to achieve the targeted goals \\
\hline NIL17 & & share knowledge and ideas for best practices \\
\hline NIL18 & & always encourage colleagues to get involved in school development programs \\
\hline NIL19 & & access and use research data to improve management practices \\
\hline NIL20 & & practice self-reflection \\
\hline NIL21 & & try to find opportunities \\
\hline NIL22 & \multirow{6}{*}{$\begin{array}{l}\text { Connecting to The Community } \\
\text { (JK) }\end{array}$} & take opportunities to achieve a vision \\
\hline NIL23 & & have the initiative to work with parents and the community \\
\hline NIL24 & & sensitive to current educational developments \\
\hline NIL25 & & have a high level of confidence to implement programs with parents and the community \\
\hline NIL26 & & sensitive to the community context and culture \\
\hline NIL27 & & acceptance of teacher perineurium to seize the opportunities available \\
\hline NIL28 & \multirow{4}{*}{ Being A Consultant (PR) } & have ethical standards to follow \\
\hline NIL29 & & strive continuously in developing creative and innovative values \\
\hline NIL30 & & constantly enhancing his leadership values \\
\hline NIL31 & & have high confidence in instructional and management \\
\hline
\end{tabular}




\subsubsection{Confirmatory Factor Analysis (CFA)}

To investigate the maximum likelihood confirmatory factor analysis of 29 items of Teacher Leadership Value Model Instrument after EFA, an AMOS software (version 20.0) was used to test the data's model fit. A data imputation was conducted on all the missing values cases, as suggested by Hair. et al. [58], [59]. The data normality was tested to eliminate any univariate outliers. A Mahalanobis distance is executed to delete the outliers from the data. Next, the Confirmatory Factor Analysis (CFA) was performed to estimate each variable's factor loading. All the latent variables have at least three indicators (questionnaire items). The loading factor achieved was greater than 0.5 , which resulted from the factor loading analysis. According to Hair et al. [58], if the loading factor is equal to or greater than 0.7 , it is considered a good indicator.

After the CFA procedure, the calculation of Convergent validity and discriminant validity tests the reliability and validity of the model. The convergent validity determines how far the items reflected the latent theoretical construct measured by the items. The discriminant validity measures how far the items will distinct from each other [58], [59]. A discriminant validity test was conducted to test each variable's significant variance for the same purpose. If the correlation between the two latent variables exceeds 0.9 , it shows an overlap between these constructs [58]. Discriminant validity was tested by comparing the square root of the AVE and the correlation between the constructs. The discriminant validity of the constructs is achieved if the AVE's square root is higher than the correlation between the constructs [62].

\section{The Findings}

\subsection{Exploratory Factor Analysis}

The EFA results on the Teacher Leadership Values instrument show that the Kaiser-Meyer-Olkin (KMO) sample adequacy test at 0.91 and Bartlett's Test of Sphericity with a chi-square value of 2712.443 at 465 degrees of independence are significant, $\mathrm{p}<0.05$. It proved that the number of samples used in EFA was sufficient [58]. Table 2 showed the Kaiser-Meyer-Olkin (KMO) and Bartlett's Test of Sphericity score for this model.

Table 2. The KMO and Bartletts's Test Score

\begin{tabular}{ccc}
\hline Kaiser-Meyer-Olkin (KMO) & $\begin{array}{c}\text { Measure of Sampling } \\
\text { Adequacy }\end{array}$ & .906 \\
\hline Bartlett's Test of Sphericity & $\begin{array}{c}\text { Approx. Chi-Square } \\
\text { Sphericity }\end{array}$ & 2712.443 \\
\hline Df & 465 \\
Sig. & .000 \\
\hline
\end{tabular}

The uniformity values of the items range from .436 to .790 . To determine the underlying factors in the instruments, the orthogonal rotation with the varimax method was performed. The orthogonal rotation is selected to ensure that the observed variables are not correlated with each other. The varimax rotation was selected to determine the factors loaded at its maximum rotation. According to Hair et al. [57], [59] any decisions on the number of factors to be retained should be based on several considerations which are, factors with eigenvalues greater than 1.0; a predetermined number of factors based on research objectives and prior research; enough factors to meet a specified percentage of variance explained, usually $60 \%$ or higher; or a scree test plot. Table 2 showed that only three factors to explain the total variance in the instruments where the Eigenvalue is greater than 1. Therefore, there are only three dimensions emerged from the EFA procedures. The eigenvalues in Table 3 ranged between 1.392 and 16.85 . The primary purpose is to maximize high factor load variance and reduce low factor load value [63]. From the analysis, the variance explained for component one is $54.35 \%$, component two is $5.513 \%$, and component three is $4.491 \%$. The total variance explained for measuring these three constructs is $64.362 \%$. The total variance explained is acceptable since it exceeded the minimum requirement of $60 \%$ [58].

Table 4 showed the three dimensions that emerged and their respective items resulted from the EFA procedure. The factor loading of more than 0.5 of every item was retained for the CFA analysis [58]. The item with lower than 0.5 loadings dropped, as suggested by Hair et al. [58]. Only two items, NIL 14 and NIL 20, dropped as the loading lower than 0.5 .

Table 3. Total variances explained

\begin{tabular}{cccccccccc}
\hline & \multicolumn{3}{c}{ Initial Eigenvalues } & \multicolumn{3}{c}{ Extraction Sums of Squared Loadings } & \multicolumn{3}{c}{ Rotation Sums of Squared Loadings } \\
\cline { 2 - 9 } Comp & Total & \% of Var & Cum \% & Total & \% of Var & Cum \% & Total & \% of Var & Cum \% \\
\cline { 2 - 10 } 1 & 16.85 & 54.35 & 54.35 & 16.851 & 54.357 & 54.357 & 7.372 & 23.780 & 23.780 \\
2 & 1.709 & 5.513 & 59.87 & 1.709 & 5.513 & 59.871 & 6.877 & 22.217 & 45.997 \\
3 & 1.392 & 4.491 & 64.36 & 1.392 & 4.491 & 64.362 & 5.693 & 18.365 & 64.362 \\
\hline
\end{tabular}


Table 4. The Exploratory Factor Analysis (EFA) components and their respective items

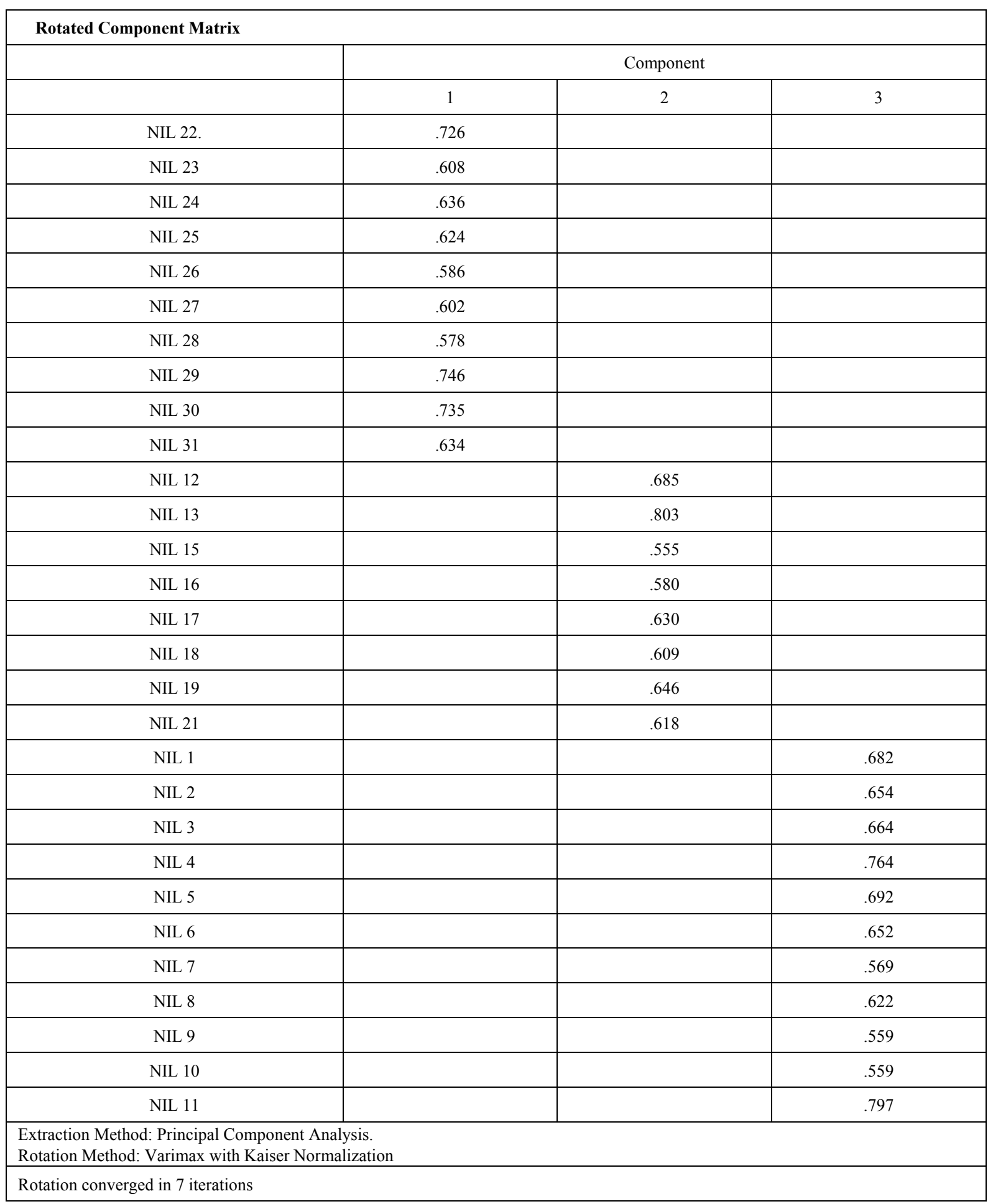

Table 5. The Internal Reliability of the constructs

\begin{tabular}{ccc}
\hline \multicolumn{2}{c}{ Reliability Statistics } & \\
\hline Component & Number of Items & Cronbach's Alpha \\
\hline Component one & 10 & .931 \\
Component two & 8 & .928 \\
Component three & 11 & .913 \\
\hline All items & 29 & 0.969 \\
\hline
\end{tabular}

Next, the Cronbach's Alpha for each of the latent construct needs to be calculated as it will reflect the Internal Reliability of the items in measuring the construct. It showed how strong the items in holding together to measure their constructs. Cronbach's Alpha's value needs to be more than 0.7 for the items achieving its Internal Reliability [58], [59]. Table 5 showed the result for the Cronbach's Alpha for each component. All the items are 
reliable since their Cronbach's Alpha is more than 0.7.

From the EFA analysis, only three dimensions emerged compared to six dimensions purposed earlier in the literature review. This instruments then regroup into a new group which are being a consultant (component one), fostering a cooperation culture (component two) and leading the teaching and learning process (component three). Details of these regrouping are stated in Table 6.

\subsection{The Confirmatory Factor Analysis}

The Confirmatory Factor Analysis (CFA) was executed on the Teacher Leadership Value Model after the EFA procedure. The instrument only consisted of three latent constructs compared to six constructs that were proposed earlier. The construct that developed is Being a Consultant (PR), Fostering a Cooperation Culture (MBK), and Leading the Teaching and Learning Process (PPdP).

Table 6. The new constructs and its respective items based on EFA result.

\begin{tabular}{|c|c|c|c|}
\hline $\begin{array}{l}\text { Item } \\
\text { Code }\end{array}$ & & Initial Construct & New Construct \\
\hline NIL 22. & take opportunities to achieve a vision & $\mathrm{JK}$ & \multirow{13}{*}{ Being a Consultant (PR) } \\
\hline NIL 23 & have the initiative to work with parents and the community & JK & \\
\hline NIL 24 & sensitive to current educational developments & $\mathrm{JK}$ & \\
\hline NIL 25 & $\begin{array}{l}\text { have a high level of confidence to implement programs with } \\
\text { parents and the community }\end{array}$ & $\mathrm{JK}$ & \\
\hline NIL 26 & sensitive to the community context and culture & $\mathrm{JK}$ & \\
\hline NIL 27 & $\begin{array}{l}\text { acceptance of teacher perineurium to seize the opportunities } \\
\text { available }\end{array}$ & JK & \\
\hline NIL 28 & have ethical standards to follow & PR & \\
\hline NIL 29 & strive continuously in developing creative and innovative values & PR & \\
\hline NIL 30 & constantly enhancing his leadership values & PR & \\
\hline NIL 31 & have high confidence in instructional and management & PR & \\
\hline NIL 12 & willing to take risks to achieve educational goals & KAdO & \\
\hline NIL 13 & ready to face challenges to achieve educational goals & KAdO & \\
\hline NIL 15 & $\begin{array}{l}\text { successfully encourages students and colleagues to achieve } \\
\text { excellence }\end{array}$ & KAdO & \\
\hline NIL 16 & able to cultivate teamwork spirit to achieve the targeted goals & MBK & \multirow{4}{*}{$\begin{array}{l}\text { Fostering a cooperation } \\
\text { culture (MBK) }\end{array}$} \\
\hline NIL 17 & share knowledge and ideas for best practices & MBK & \\
\hline NIL 18 & $\begin{array}{l}\text { always encourage colleagues to get involved in school } \\
\text { development programs }\end{array}$ & MBK & \\
\hline NIL 19 & access and use research data to improve management practices & MBK & \\
\hline NIL 21 & try to find opportunities & MBK & \multirow{12}{*}{$\begin{array}{l}\text { Teaching and Learning } \\
\text { Process (PPdP) }\end{array}$} \\
\hline NIL 1 & Adhere to a comprehensive philosophy of national education & PPdP & \\
\hline NIL 2 & exhibit a variety of leadership values and behaviors & PPdP & \\
\hline NIL 3 & learn from their own experience & PPdP & \\
\hline NIL 4 & have a high commitment to fulfil students need & PPdP & \\
\hline NIL 5 & adopt a culture of cooperation to maximize student performance & PPdP & \\
\hline NIL 6 & exhibit sensitivity to the diversity that exists in the classroom & PPdP & \\
\hline NIL 7 & $\begin{array}{l}\text { honest and humble in the effort to build positive interactions } \\
\text { with fellow teachers and students }\end{array}$ & MI & \\
\hline NIL 8 & adopt a culture of creativity and innovation & MI & \\
\hline NIL 9 & able to apply ethics / integrity in leadership practices & MI & \\
\hline NIL 10 & have a high commitment to meet students need & MI & \\
\hline NIL 11 & $\begin{array}{l}\text { creative in fostering good decision-making skills among friends } \\
\text { and students }\end{array}$ & MI & \\
\hline
\end{tabular}




\subsubsection{The Goodness of Fit Indexes}

The maximum likelihood Confirmatory Factor Analysis (CFA) was used to assess the underlying latent variable structure existed in the Teacher Leadership Value Model Instrument. Standardized loading estimates on each factor must distinguish between .5 and ideally .7 or higher [58]. A higher loading means that the items are strongly related to their constructs. Lower estimates values will be suggested that the items should be dropped. For this model to achieve the acceptable fit, the following indexes are required: $\mathrm{CMIN} / \mathrm{DF}<5.0$, Comparative fit index $(\mathrm{CFI})$ $\geq 0.90$, adjusted goodness-of-fit index (AGFI) $\geq 0.90$, root mean square error of approximation (RMSEA) $\geq 0.90$, Tucker-Lewis Index (TLI) $\geq 0.90$ and standardized root mean square residual $(\mathrm{SRMR}) \leq 0.06$ [64] [65] [66]. This measurement model of teacher leadership value was accepted if the teacher leadership value model has met at least one of the goodness of fit indices from each category of the goodness of fit model [58].

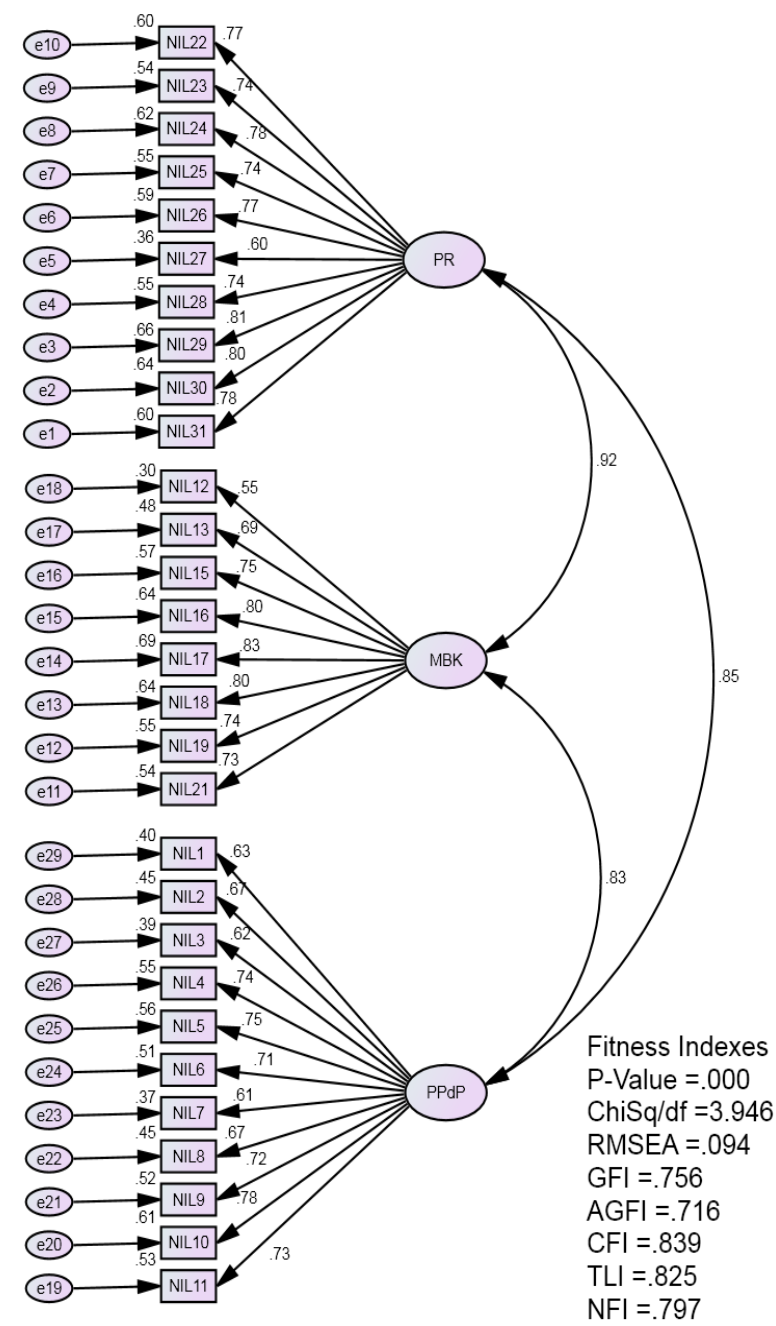

Figure 1. The initial CFA of Teacher Leadership Value Model: Being a Consultant (PR), Fostering Cooperation Culture (MBK) and Leading the teaching and learning process (PPdP).
Figure 1 showed the result of Confirmatory Factor Analysis on the Teacher Leadership Value Instrument. The analyzed data showed that it did not fit the specified factorial structure. The chi-square value, CMIN/DF is 3.946 (achieved the threshold of 5.0), RMSEA is 0.094 (achieved the threshold of $\geq 0.90$ ), GFI is 0.756 (not achieved the threshold of $\geq 0.90$ ), AGFI is 0.716 (is not achieved the threshold of $\geq 0.90$ ), CFI is 0.839 (is not achieved the threshold of $\geq 0.90$ ) and TLI is 0.825 (is not achieved the threshold of $\geq 0.90$ ). Examination on the modification indices showed that items with higher error terms need to be deleted to achieve the model fit indices requirement.

In the construct of Being a Consultant (PR), three items were deleted. NIL 27 (teachers need to have entrepreneurial value to seize the opportunities), NIL 29 (teachers need to work continuously in developing creative and innovative values), and NIL 30 (teachers always strive to increase the value of their leadership) dropped. In the construct of the fostering cooperation culture (MBK), two items were deleted. NIL 12 (teachers are willing to take risks to achieve the educational goals) and NIL 16 (teachers can cultivate teamwork spirit to achieve the targeted goals) dropped.

Meanwhile, six items were deleted in the third construct of leading the teaching and learning process (PPdP). NIL 1 (teachers need to adhere to a comprehensive educational philosophy), NIL 2 (teachers need to demonstrate a variety of leadership values and behaviors), NIL 3 (teachers can learn from their own experience), NIL 4 (teachers committed to meet the student's needs), NIL 5 (teachers practice collaboration among them to maximize their student performance), and NIL 7 (teachers should be honest and humble in their efforts to build positive interactions with peers and students) dropped. After all the items deleted, the Teacher Leadership Value Instrument achieved a good fit, with Chisq/df of 2.368 (achieved the threshold of 5.0), RMSEA is 0.064 (achieved the threshold of $\geq 0.90$ ), GFI is 0.912 (achieved the threshold of $\geq 0.90$ ), AGFI is 0.884 (is not achieved the threshold of $\geq 0.90$ ), CFI is 0.955 (achieved the threshold of $\geq 0.90$ ), TLI is 0.947 (achieved the threshold of $\geq 0.90$ ) and NFI is 0.924 (achieved the threshold of $\geq 0.90$ ). According to Hair et al. [58], [59], they must achieve at least one absolute fit index and one incremental fit index as an addition to the $\chi^{2}$ statistics result. In the Absolute Fit category, the RMSEA and GFI meet the required threshold. In the Incremental Fit category, the NFI, CFI, and TLI meet the requirement for model fit. Next, in the Parsimonious fit category, the chisq/df achieved the required threshold given. Therefore, the measurement of all the latent constructs in Figure 2 fulfilled the requirement for construct validity [58], [59]. All the fitness indexes for this model showed in Table 4. 


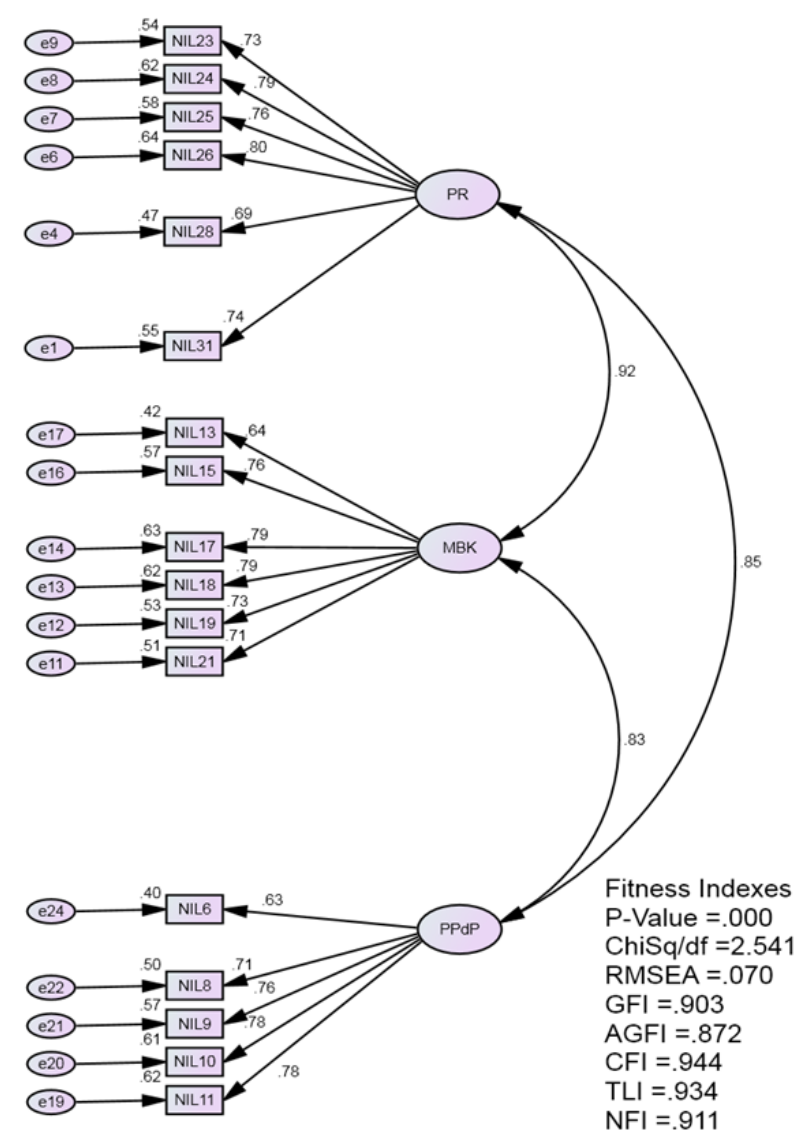

Figure 2. The Teacher Leadership Value Model: Being a consultant (PR), Fostering cooperation culture (MBK), and Leading the teaching and learning process (PPdP).

Table 7. The results of CFA First Order on Teacher Leadership Value Instrument

\begin{tabular}{cccc}
\hline No & Category & $\begin{array}{c}\text { Types of Fitness } \\
\text { Index }\end{array}$ & $\begin{array}{c}\text { Index } \\
\text { Value }\end{array}$ \\
\hline 1 & Absolute fit & RMSEA & .070 \\
& & GFI & .903 \\
2. & Incremental fit & CFI & .944 \\
& & TLI & .934 \\
& & NFI & .911 \\
3 & Parsimonious fit & Chisq/df & 2.541 \\
\hline
\end{tabular}

4.2.2. The Validity and Reliability of the Teacher Leadership Value Construct

To determine the Convergent Validity of this instrument, the computation of the Average Variance Extracted (AVE) needs to be executed first. This instrument will achieve convergent validity if its AVE greater than the threshold value at 0.5 [67]. Then, the composite reliability determined by computation of Construct reliability (CR) values, and its value must not exceed 0.7 for the reliability [58] [59]. Based on Table 5, the Composite Reliability value for CFA also met the prescribed value of $\geq 0.6$. Whereas, the Composite Reliability value sub-constructs of being a consultant (PR), fostering a cooperation culture
(MBK), and leading the teaching and learning process (PPdP) are 0.88, 0.88, and 0.85. For the Average Variance Extracted (AVE) value, the sub-construct of being a consultant recorded (PR) 0.57, fostering a cooperation culture (MBK) is 0.55 while leading the teaching and learning process (PPdP) is 0.54 . All the values obtained have met the prescribed criteria where the AVE value is $\geq$ 0.5 .

Table 8. The results of the CFA Teacher Leadership Value Measurement Model

\begin{tabular}{ccccc}
\hline Construct & Item & $\begin{array}{c}\text { Factor } \\
\text { Loading }\end{array}$ & $\begin{array}{c}\text { CR } \geq \\
0.70\end{array}$ & $\begin{array}{c}\text { AVE } \geq \\
0.50\end{array}$ \\
\hline \multirow{5}{*}{ PR } & NIL 23 & .73 & & \\
& NIL 24 & .79 & & \\
& NIL 25 & .76 & .89 & .57 \\
& NIL 26 & .80 & & \\
& NIL 28 & .69 & & \\
& NIL 31 & .74 & & .55 \\
MBK & NIL 13 & .64 & & \\
& NIL 15 & .76 & & \\
& NIL 17 & .79 & & \\
& NIL 18 & .79 & & \\
& NIL 19 & .73 & & \\
& NIL 21 & .71 & & \\
\hline \multirow{5}{*}{ PPdP } & NIL 6 & .63 & & \\
& NIL 8 & .71 & & \\
& NIL 9 & .76 & .85 \\
& NIL 10 & .78 & \\
NIL 11 & .78 & \\
\hline
\end{tabular}

\section{Discussion}

The result of this study showed that the existing proposed instrument with six constructs, which are Leading Teaching and Learning Process, Being A Follower, Involving Actively in the Organisation, Fostering Cultural Cooperation, connecting to the Community and Being A Consultant are not fit to the model. After the Exploratory Factor Analysis (EFA) and Confirmatory Factor Analysis (CFA) performed, only three constructs were fit in the model which are Being a consultant (PR), Fostering cooperation culture (MBK), and Leading the teaching and learning process (PPdP). All the proposed 31 items were reduced to only 17 items in improving the model fit and parsimony.

This study confirmed that teachers being a consultant is one of the important values in teacher leadership skills. It is a value that allowed the teachers to work closely with parents, community and be sensitive towards the latest educational development. It also encouraged them to increase their confidence level and be sensitive to the community's culture and context. It will guide them in their 
everyday lives and make them believe in the instructional and management. The teacher leaders who are competent and committed can carry out entrusted responsibilities [68]. Teachers also can easily collaborate and often become references to other teachers and parents. These findings were supported by a study conducted by [69], which stated that the teachers who have the expertise and ability could influence others. Teachers who have the qualities of a leader will be able to carry out their duties as advisors and mentors to help their colleagues and bring positive changes to the school atmosphere [55]. The committed teachers always contribute more than expected as they believe that it will set an example for their students and the school community. They are aware that their responsibility influences the students and their colleagues to achieve the desired goals in line with the school's vision and mission.

A study by Suriansyah and Aslamiah [70] stated that teachers who showed an excellent manner to their students, respect the students, dress appropriately, punctual, and always care about cleanliness in the classroom can be an excellent example to the students. Their study also proved that active teacher participation in teaching and learning would help develop students' characters. It includes their daily communication, encourages them to engage actively in the classroom and seeks changes and emotional development in everyday activities. A study of Lowery-Moore, Latimer and Villate [71] supports this research; they mentioned that teacher leadership would make teachers better understand their relationship to the schools and community. Teachers will also feel more comfortable finding answers to new questions as they help their schools and community move forward. Therefore, this study's finding confirmed that this construct is one of the most critical constructs in teacher leadership in terms of values.

The second construct developed in this model is fostering a cooperation Culture (MBK) construct. This construct measured teachers' value in terms of their willingness to face the challenges; encouraging colleagues and students to excel; sharing knowledge and ideas for best practices; encouraging colleagues to be involved in school improvement programs; using research to improve management practices, and being able to seek new opportunities. Cooperation culture or collaboration culture also refers to teacher commitment to perform and carry out the task, trust, and responsibility. Each task must be done collectively, according to Dahlgren and Chirac's [48] study. This study was supported by a study of Prugsamatz [51], where he proved that the group's work has a strong influence on organizational learning. Another study by Ciampa and Gallagher [72] stated that teacher collaboration changed the teacher's instructional and assessment practices and self-efficacy. The collaboration with other teachers in sharing knowledge and future planning will encourage them to take more risks, creativity, develop their intrinsic motivation, and increase their professional satisfaction. A study by Wan and Mohd. Sabri [73] also stated that collaboration is a continuous learning process and as a medium of sharing pieces of knowledge among teachers. Through collaboration, the mission and vision in the school are easier to achieve. According to Pang and Miao [74], collaboration and teamwork are the priority in everyday management and teacher leaders' administration.

A teacher must not work alone to meet the student's and schools' needs in general. They should cooperate with others to obtain multiple sources [75]. This cooperation or collaboration is essential for teachers to achieve their common goals as they have their specialities [76] and provide more space for teachers to apply these skills, especially when dealing with pupils in the classroom [77]. Cultural cooperation also indirectly helps teachers to obtain additional information to develop their potential. The value of cooperation culture can avoid misunderstandings and dissatisfaction among the teachers [78]. A study by Mohd Faiz, Muhammad Rozaimie, and Jamal [79] stated that teachers collaborate at school through Professional Learning Community (PLC). In PLC, teachers are actively involved in communications with other teachers. They will be discussing their daily routines or problems inside the classroom with other teachers. Then, this discussion will lead to the development of teachers' pedagogical strategies and, thus, support each other in trying new methods inside the classroom. In other words, the value of fostering a collaborative culture is capable of forming a team that aims to ensure school success [55].

Teacher leaders are capable of fostering a teamwork culture with their peers. A study conducted by Berry, Daughtery and Wider [80] states that schools with an abundance of experience teachers and specialists in education will produce an outstanding achievement through working with their peers. The sharing session with new teachers will help their peers improve their teaching and learning methods in the classroom. This study was supported by Riveros, Newton, and Costa [81], who stated that teacher leadership would contribute to teacher professional development. A survey conducted by Pang and Miao [74] on teacher leadership practice in education reform in Shanghai revealed that Shanghai teachers play an essential role in collaborating and thus supporting school improvement. According to their research, teachers will help other teachers deal with education problems to ensure that educational excellence is shared.

A study conducted by Flores, Fernandes, Flores, and Forte [82] on teachers in Portugal found that collaboration between teachers is critical in their daily lives. Collaboration between fellow teachers is crucial in sharing ideas, materials, and also reflected on their teaching. According to a study conducted by the Rennie Center for Education Research \& Policy [83], schools with higher collaboration levels are associated more with excellent student achievement. This study shows that teachers will 
produce great students when they are at the school that promotes collaboration with colleagues. This collaboration allows them to discuss instructional issues, irrespective of their educational background, experience, or student achievement. Studies show that teachers are more comfortable discussing their instructional problems with their colleagues than with the principals or officials involved. This evidence shows that teacher collaboration is essential in driving school improvement, creating an environment for teachers to improve their teaching while helping students meet their diverse needs. Cosenza [84] found that teachers look at themselves as acting leaders when they collaborate. Through collaboration, they can make decisions that enhance their teaching and provide support for each other. According to them, this is the definition of teacher leadership they know. Besides, they also said that the sharing of best practice was through collaboration with each other. Teachers feel they are fully empowered when they share their teaching practice with their colleagues.

The third construct found in this study is leading the teaching and learning process (PPdP). Leading the teaching and learning process includes the value of sensitivity towards diversity in the classroom, practising a culture of creativity and innovation, applying ethics, and having a strong commitment and creativity in decision making. The study of Southworth [85] found that teacher leadership is closely related to teaching and learning, including teachers' professional learning and students' development. The teachers' duties and responsibilities as the leader of the teaching and learning process are not only focused on the students but also cover the entire school community. Nowadays, the roles of the teachers themselves have been very complex and challenging. Therefore, teachers should strive to improve their teaching professionalism so that the teaching profession's dignity will be respected continuously. Teachers will support one another in the efforts to enhance teaching and clinical engagement [86].

Rahayu's study [87] showed that the changing of teaching and learning methods in Chemistry subjects from traditional approaches to innovative ways resulted in improving student results. The student's achievement showed that $100 \%$ of the students scored 70 marks and above, the quality of learning also improves by more student's handover their assignments in time, their interaction and communication in using the English language as a medium increase, and their perspective towards the subjects change drastically. Most of them stated that they feel excited to learn the subject, which helps them understand the subject better. This study proved that the teacher's approach to delivering teaching and learning could be subject to students' achievement in the subject. The teachers are fully responsible for teaching and learning, not only in the classroom but also in the other areas of the school environment. Thus, effective teaching can lead to student achievement [88].
Davies and Brighouse [89] study mentioned that to create learning momentum in the classroom, build the capacity, ensure the environment, continue the vision, face and minimize the crisis, and search and chart the progress will help teachers to find direction in teaching and learning process. A study by Tan, Ooi and Teh [90] found that $60 \%$ of trainee teachers showed an improvement in their quiz questions when engaging in lesson study and gallery tour collaboration activities. This study is in line with Zetty, Siti Rashidah, Norshilawani, Ahmad Shafiq, Zanaton and Sri Andayani [91] the teaching of Islamic education through the lesson study culture. They found that teachers need to share their best practices in teaching. Every teacher has a wide range of skills; through the learning process, they can share their skills and expertise in solving problems encountered in the subject. This study will indirectly contribute to student understanding and thus enhance student achievement. Therefore, this study proved that all the three constructs developed in this instrument, which are Being a consultant (PR), Fostering cooperation culture (MBK), and Leading the teaching and learning process (PPdP), are crucial values in Teacher Leadership Value Model.

\section{Conclusions}

The results of this study allow various parties, particularly the Ministry of Education (MOE), to review the training and selection of prospective teachers to produce teachers with high leadership values. The results also can help the ministry to take appropriate steps to produce world-class teachers. This study is also essential to institutions such as educational institutions, both private and local, to train the teachers and prospective teachers to balance in terms of values, knowledge, and skills. The training provided can produce teacher leaders who have the leadership qualities described in the Malaysian Teachers Standard (Standard Guru Malaysia). School authorities should civilize teacher leadership values among the teachers and students in school. It can improve teachers' service quality, which can produce a balanced human capital in line with the National Philosophy of Education.

\section{Acknowledgement}

This paper is financially supported by the Niche Research Grant funding by the Ministry of Higher Education Malaysia, gran no. NRGS 2014-00001-107-82-4. Thank you, University Pendidikan Sultan Idris, for this opportunity.

\section{REFERENCES}

[1] Siti Salwa., Azlina. "Guru bersahsiah mulia menurut 
pandangan Ibnu Sahnun: Analisa buku adab Al-Mualimin [The teacher has a noble personality according to Ibn Sahnun: An analysis of the book of adab Al-Mualimin]". Journal of Islamic Education, vol. 2 no.2.

[2] Hanim., Siti Maisarah. "Sikap guru terhadap factor penentu iklim sekolah di sebuah sekolah menengah swasta di daerah Johor Bahru [Teachers' attitudes towards school climate determinants in a private secondary school in Johor Bahru district]". http://eprints.utm.my/11701/1/Sikap Guru Terhadap Faktor Penentu Iklim Sekolah di Sebuah.pdf (Retrieved 7 April 2020).

[3] Ibrahim, T., Marzuki, N. "Kualiti guru permulaan: Pendekatan model persamaan structural [Quality of new teachers: A structural equation model approach].” Seminar of the Council of Deans of the Faculty of Education IPTA 2011. Serdang, Faculty of Education, Universiti Kebangsaan Malaysia.

[4] Baharin, A., Suzana, M. "Pengetahuan etika profesion perguruan dalam kalangan guru pelatih 4SPH [Knowledge of college professional ethics among 4SPH trainer teachers]". Faculty of Education, Universiti Teknologi Malaysia. https://eprints.utm.my/10740/1/Pengetahuan Etika Profesion Perguruan dalam Kalangan Guru Pelatih 4SPH Fakulti Pendidikan, UTM. (Retrieved 7 April 2020).

[5] Azlina, M. K., Tan, S. L. "Pengaruh personaliti terhadap kepuasan kerja dan stress kerja guru [The influence of personality on job satisfaction and job stress of teachers]". Jurnal Teknologi. https://doi.org/10.11113/jt.v48.244 (Retrieved 24 July 2020)

[6] Zakaria, S., Ahmad Munawir., Noranizah, Y. "Faktor persekitaran sosial dan hubungannya dengan pembentukan jati diri [Social environmental factors and their relationship with the formation of identity]". Jurnal Hadhari, Special edition. pp. 155-172. ISSN 1985-6830. http://ejournals.ukm .my/jhadhari (Retrieved 7 April 2020).

[7] Lickona, T. "Educating for character: How our schools can teach respect and responsibility." New York: Bantam Books, 1991

[8] Abdullah, I. "Sejarah Perkembangan Pelajaran dan Pendidikan Islam [History of the Development of Islamic Education]." Kuala Lumpur: Malaysian Da'wah and Welfare Unit.

[9] Nik Aziz, N. P. "Pendidikan dan nilai di Malaysia: Satu analisis tentang konsep dan realiti dari perspektif bersepadu [Education and values in Malaysia: An analysis of concepts and reality from an integrated perspective]". Jurnal Kebajikan Masyarakat, vol.19 no.2, pp.1-22.

[10] Apidah, A. N. "Profil personaliti guru-guru prasekolah berdasarkan MBTI [Personality profiles of preschool teachers based on MBTI]". Phd Thesis. Selangor, Universiti Kebangsaan Malaysia.

[11] Gamal, A. N. "Prinsip-prinsip pendidikan Islam [Islamic education principles]". Pahang: PTS Publication and Distributors Sdn. Bhd, 2003.

[12] Akhiar, P., Shamsina, S., Muhammad Khusairi, J. “Asas Kepimpinan dan Perkembangan Professional Guru [Fundamentals of Teacher Leadership and Professional Development]”. Kuala Lumpur: Freemind Horizons Sdn. Bhd, 2012.
[13] Lambert, L. C. M., Dietz, ME, Kent, K., Richert, AE. "Who will save our schools: Teachers as constructivist leaders?" Corwin Press, 1996.

[14] Johnson, J., Hynes, M. C. "Teaching/learning/leading: Synonyms for change." Action in Teacher Education, vol.19 no.3, pp107-119.

[15] Dozier, T. K. "Turning good teachers into great leaders." Educational Leadership, vol.65 no.1, pp54.

[16] Bond, N. "Preparing preservice teachers to become teacher leaders." The Educational Forum, vol.75 no.4, pp280-297.

[17] Huggins, K. S., Lesseig, K. Rhodes, H. "Rethinking Teacher Leader Development: A study of early Career Mathematics Teachers." International Journal of Teacher Leadership, vol. 8 no.2, pp28-48. https://files.eric.ed.gov/fulltext/EJ1169799 .pdf (Retrieved 3 March 2020).

[18] Wenner, J. A., Campbell, T. "The Theoretical and Empirical Basis of Teacher Leadership." Review of Educational Research, vol.87 no.1, pp134-171. https://doi.org/10.3102/ 0034654316653478 (Retrieved 24 January 2020).

[19] Lieberman, A., Miller, L. "What research says about teacher leadership." In R. H. Ackerman, \& S. V. MacKenzie (Eds.), Uncovering teacher leadership. Thousand Oaks, CA: Corwin Press, 2007, pp37-50.

[20] Sinha, S., Hanuscin, D. L. "Development of teacher leadership identity: A multiple case study." Teaching and Teacher Education, vol. 63, pp356-371. https://doi.org/10.1016/j.tate.2017.01.004 (Retrieved 2 January 2020).

[21] Mohd Yusof, A., Salleh, A.R., Zulkifli, M. "Kekuatan hubungan motif, sikap dan latihan perguruan dengan profesionalisme keguruan pelajar tahun akhir program pendidikan di IPTA [The strength of the relationship between motives, attitudes and college training with teacher professionalism in the final year of education programs at IPTA]". Malaysian Education Deans' Council Journal, USM.

[22] Ministry of Education, Malaysia, MOE. “Works Ethique." Kuala Lumpur: KPM.

[23] Murphy, J. "Connecting Teacher Leadership and School Improvement." Thousand Oaks, CA: Corwin Press, 2005.

[24] York-Barr, J., \& Duke, K. "What do we know about teacher leadership? Findings from two decades of scholarship". Review of Educational Research, vol.74, pp255-316. https://doi.org/10.3102/00346543074003255 (Retrieved 24 July 2020).

[25] Katzenmeyer, M., Moller, G. "Awakening the sleeping giant: Helping teachers develop as leaders (2nd ed.)". Thousand Oaks, CA: Corwin Press, 2001.

[26] Uribe-Florez, L., Al-Rawashdeh, A., Morales, S. "Perceptions about teacher leadership: Do teacher leaders and administrators share a common ground?" Journal of International Education and Leadership, vol.4 no.1, pp1-15. https://files.eric.ed.gov/fulltext/EJ1136038.pdf (Retrieved 3 June 2020).

[27] Harris, A. Muiijs, D. "Teacher Leadership. A review of research". University of Warwick, 2005. 
[28] Mangin, M. M., Stoelinga, S. R. "Teacher leadership: What it is and why it matters." In M. M. Mangin \& S. R. Stoelinga (Eds.), Effective teacher leadership: Using research to inform and reform. New York, NY: Teachers College Press, 2008, pp1-9.

https://www.researchgate.net/publication/323116238 Teac her_Leadership_Going_Beyond_Classroom (Retrieve 7 January 2020).

[29] Ismail, A. "Peranan Guru Membina Murid Menghadapi Cabaran Wawasan 2020 [The Role of Teachers in Pupils development to Face Vision 2020 Challenges]". Jurnal Penyelidikan Pendidikan Institut Perguruan Islam, vol.10, pp82-89.

https://www.scribd.com/document/46460260/Peranan-Guru -Membina-Murid-Menghadapi-Cabaran-Wawasan-2020-Ke rtas-Konsep (Retrieved 2 May 2020).

[30] Helterbran, V. R. "Teacher leadership: Overcoming "I am just a teacher syndrome." Education, vol.131 no.2, pp363-371. http://eric.ed.gov/?id=EJ930607 (Retrieved 24 May 2020).

[31] Brenneman, R. "Teacher leadership makes inroads but strives for permanency." Education Week, vol.18 no.21. http://www.edweek.org/tm/articles/2015/02/18/teacher-lead ership-makes-inroads-but-strives-for.html (Retrieved 2 January 2020).

[32] Mohd. Arif, I., Mohd. Jasmy, A.R., Rosnani, M. "Nilai-nilai murni dan pendidikan bersepadu: ke arah kemanusiaan sejagat [Virtuous values and integrated education: towards universal humanity]." Islamic Education discourse proceedings (series 4): Islamic education towards universal humanity. Bangi: Faculty of Islamic Education, Universiti Kebangsaan Malaysia.

[33] Rokeach, M. “The nature of human values." New York: Free Press, 1973.

[34] Schwartz, S. H. "Universals in the content and structure of values: Theoretical advances and empirical tests in 20 countries". Advances in experimental social psychology, vol.25 no.1, pp1-65.

[35] Institut Tadbiran Awam Negara (INTAN). “Tonggak 12 [Twelve Pillars]". https://www.scribd.com/document/2535 627/TONGGAK12 (Retrieved 2 March 2020).

[36] Malaysia Ministry of Education. "Malaysian Teacher Standards, ” Putrajaya: Teacher Education Division, 2009.

[37] Shippen, M. E., Shippen, S. J. "Seven characteristics of effective leaders." Classroom Leadership, vol.7 no.8.

[38] Zenger, J. H., Folkman, J. "The handbook for leaders: 24 lessons for extraordinary leaders". New York: McGraw-Hill, 2004.

[39] Macnab, D. S., Payne, F. "Beliefs, attitudes and practices in mathematics teaching: Perceptions of Scottish primary school student teachers." Journal of Education for teaching, vol.29 no. 1, pp55-68.

[40] Danielson, C. "Teacher leadership that strengthens professional practice.” ASCD, 2006.

[41] Chek Mat. "Kemahiran Memimpin [Leadership Skills]". Kuala Lumpur: Utusan Malaysia, 2003.

[42] Helm, C. "Leadership dispositions: What are they and are they essential to good leadership." Academic Leadership: The Online Journal, vol.8 no.1, pp21.

[43] Ciulla, J. B. "Ethics and leadership effectiveness." The nature of leadership, pp302-327.

[44] Suranna, K. J., Moss, D. M. "Exploring leadership in the context of teacher preparation." In New Orleans: Annual Meeting of the Educational Research Association.

[45] Angelle, P. S., Nixon, T.J., Norton, E.M., Niles.C.A. "Increasing organizational effectiveness: An examination of teacher leadership, collective efficacy, and trust in schools." Paper presented at the annual meeting of the University Council for Educational Administration, Pittsburgh, 19 November 2011. https://pdfs.semanticscholar.org/2de6/e10 d857e056506a7e456f4a58dc3f90a461c.pdf?_ga=2.5701307 963602106.1572517290-1405708887.1561986842 (Retrieved 23 June 2020).

[46] Hope-Arlene, F. "Planting seeds for change: fostering leadership." Planning and Changing, vol.30 no.3/4, pp175-197.

[47] Suranna, K. J., Moss, D. M. "Perceptions of Teacher Leadership: A Case Study of Inservice Elementary School Teachers."

[48] Durr, A.J., “Teacher Education's Critical Issues with Teacher Quality." Paper presented at the Annual Meeting of the MWERA Annual Meeting. https://www.allacademic.com/meta/p275298 index. html. 25 November 2008 (Retrieved 24 January 2020).

[49] Dahlgren, M. A., Chiriac, E. H. "Learning for professional life: Student teachers' and graduated teachers' views of learning, responsibility and collaboration." Teaching and Teacher Education, vol.25 no.8, pp991-999.

[50] Gregory, A. "Teaching learning on problem-solving teams." Teaching and Teacher Education, vol.26, pp608-615.

[51] Prugsamatz, R. "Factors that influence organization learning sustainability in non - profit organizations." The learning organization.

[52] Sun, M., Penuel, W. R., Frank, K. A., Gallagher, H. A., Youngs, P. "Shaping professional development to promote the diffusion of instructional expertise among teachers." Educational Evaluation and Policy Analysis, vol.35 no.3, pp344-369.

[53] Fairman, J. C., Mackenzie, S. V. "How teacher leaders influence others and understand their leadership." International Journal of Leadership in Education, vol.18 no.1, pp61-87.

[54] Teacher Leadership Exploratory Consortium. "Teacher Leader Model Standards." http://www. teacherleaderstanda rds.org/downloas/TLS_Brochure_sm.pdf (Retrieved 24 January 2020).

[55] Abdullah, S. Y., Abdul Rashid, M. Abdul Ghani, A. "Guru Sebagai Pemimpin [Teacher as a leader]”. Kuala Lumpur: PTS Profesional Publishing, 2007.

[56] Nur Hafizoh, I., Rohana, H. "Nilai Profesionalisme Bakal Guru Berteraskan Indikator Standard Guru Malaysia [The Value of Professionalism of Prospective Teachers Based on Malaysian Standard Teacher Indicators]," Jurnal Teknologi. https://www.academia.edu/33744618/Nilai Profesionalism 
e Bakal Guru Berteraskan Indikator Standard Guru Mal aysia_SḠM_(Retrieved $24 \bar{J}$ January 2020$)$.

[57] Nolan, B., Palazzolo, L. "New teacher perceptions of the teacher leader movement." NASSP Bulletin, vol.95 no.4, pp302-318.

[58] Hair, J.F., Black, W.C., Rabin, B.J., Anderson, R.E. "Multivariate Data Analysis (7 Ed)", Englewood Cliffs, NJ: Prentice-Hall, 2010. https://is.muni.cz/el/1423/podzim2017/PSY028/um/ Hair Multivariate_data_analysis_7th_revised.pdf (Retrieved $\overline{1} 8$ January 2020).

[59] Hair, J. F., Black, W. C., Babin, B. J., \& Anderson, R. E. "Multivariate data analysis: Pearson new international edition.” Essex: Pearson Education Limited, 2014.

[60] Tuckman, B. W. Waheed, M. A. "Evaluating an individual science programme for community college students." Journal of Research in Science Teaching, vol.18, pp489-95.

[61] Henson, R. K., Roberts, J. K. "Use of exploratory factor analysis in published research: Common errors and some comment on improved practice." Educational and Psychological Measurement, vol.66 no.3, pp393-416.

[62] Zainuddin Awang. "Structural Equation Modeling Using Amos Graphic." Shah Alam: Universiti Teknologi MARA Publication Centre (UiTM Press), 2012.

[63] Tabachnick, B. G., Fidell, L. S. "Using Multivariate Statistics." Allyn \& amp; Bacon. Google Scholar Google Scholar, Digital Library Digital Library, 2006.

[64] Bentler, P. M. "Comparative fit indexes in structural models." Psychological Bulletin, vol.107 no.2, pp238.

[65] Segar, H., Grover, V. "Re-examining perceived ease of use measurements and perceived usefulness." Decision Sciences, 1993

[66] Byrne, B. M. "Structural equation modelling with EQS. Basic concepts. Applications, And Programming”, Lawrence Erlbaum Associates, 2006.

[67] Fornell, C., Larcker, D. F. "Structural equation models with unobservable variables and measurement error: Algebra and statistics," 1981.

[68] Aziah, I., Abdullah, S. "Kepentingan Kapasiti Kepimpinan Guru Dalam Pengurusan Sekolah [The Importance of Teacher Leadership Capacity in School Management]". Diges Pendidik, vol.8 no.2, pp64-70.

[69] Syed Ismail, S. M., Ahmad Subki, M. “Asas kepimpinan dan Perkembangan Professional [Basic Leadership and Professional Development]". Selangor: Multimedia Publishing Sdn. Bhd, 2010.

[70] Suriansyah., Ahmad., Aslamiah. "Strategi Kepemimpinan Kepala Sekolah, Guru, Orang Tua, dan Masyarakat dalam Membentuk Karakter Siswa [Leadership Strategies of Principals, Teachers, Parents, and Society in Shaping Student Character]". Jurnal Cakrawala Pendidikan. https://doi.org/10.21831/cp.v2i2.4828 (Retrieved 22 April 2020).

[71] Lowery-Moore, H., Latimer, R. M., Villate, V. M. "The Essence of Teacher Leadership: A Phenomenological Inquiry of Professional Growth." International Journal of
Teacher Leadership, vol.7 no.1, pp1-16.https://files.eric.ed. gov/fulltext/EJ1137503.pdf (Retrieved 24 July 2020)

[72] Ciampa, K., Gallagher, T. L. "Teacher collaborative inquiry in the context of literacy education: Examining the effects on teacher self-efficacy, instructional and assessment practices." Teachers and Teaching, vol.22 no.7, pp858-878.

[73] Wan, N. A., Mohd Sabri. "Pelaksanaan amalan kepemimpinan kolaboratif dalam kalangan pemimpin instruksional bagi memperkasakan pendidikan matematik sekolah rendah [Implementation of collaborative leadership practices among instructional leaders to strengthen primary school mathematics education]". $\mathrm{PhD}$ thesis, University of Malaya. http://studentsrepo.um.edu.my/7358/ (Retrieved $3^{\text {rd }}$ February 2020).

[74] Pang, N. S. K., Miao, Z. "The Roles of Teacher Leadership in Shanghai Education Success." Bulgarian Comparative Education Society.

[75] Yahya, D., Aziah., Yaakob, D. "Kepimpinan \& Pembangunan Pelajar Sekolah di Malaysia [School Student Leadership \& Development in Malaysia]". PTS Professional Publishing Sdn. Bhd, 2007.

[76] Collay, M. "Everyday teacher leadership: Taking action where you are (Vol. 14)”. John Wiley \& Sons, 2011.

[77] Tang, K.N. "A comparative study on teacher leadership in special education classroom between China and Malaysia." Procedia Social and Behavioural Sciences, vol.31, pp231-235.

[78] Abdallah, J. "Lowering teacher attrition rates through collegiality." Academic Leadership: The Online Journal, vol7 no.1, pp24.

[79] Mohd Faiz, Muhamad Rozaimi, R., Jamal@Nordin. "Konsep Kolaborasi Dalam Komuniti Pembelajaran Professional: Satu Tinjauan Dari Perspektif Islam [The Concept of Collaboration in the Professional Learning Community: An Overview from an Islamic Perspective]". Malaysian Journal of Society and Space, vol.12 no.10, pp1-9. http://ejournal.ukm.my/gmjss/article/view/17747/5484 (Retrieved 2 April 2020)

[80] Berry, B., Daughtry, A., Wieder, A. "Teacher leadership: Leading the way to effective teaching and learning." https://files.eric.ed.gov/fulltext/ED509719.pdf (Retrieved 2 April 2020).

[81] Riveros, A., Newton, P., Costa, J. D. "From Teachers to Teachers-Leaders: A Case Study." International Journal of Teacher Leadership, vol.4 no.1, pp1-15. https://files.eric.ed.gov/fulltext/EJ1169800.pdf (Retrieved 23 July 2020).

[82] Flores, M. A., Fernandes, E., Flores, M. e Forte, A. "Conditions for teacher leadership and professional development in challenging circumstances," in B. de Wever, R. Vanderlinde, M. Tuytens, A. Aelterman (Eds) Professional Learning in Education. Challenges for Teacher Educators, Teachers and Student Teachers, Ghent: Academic

[83] Rennie Center of Education Research \& Policy. "Alternative Education: Exploring Innovation in Learning." http://www.renniecenter.org/sites/default/files/2017-02/Alte rnativeEducation $\% 20-\% 20$ Exploring\%20Innovations $\% 20$ in 
\%20Learning_0.pdf(Retrieved 24 July 2020).

[84] Cosenza, M. N. "Defining Teacher Leadership: Affirming the Teacher Leader Model Standards," vol.24 no.2, pp79-99. https://files.eric.ed.gov/fulltext/EJ1090327.pdf (Retrieved 25 July 2020).

[85] Southworth, G. "Instructional leadership in schools: Reflections and empirical evidence." School Leadership and Management, vo.22 no.1, pp73-92.

[86] Abdul Rahman, N. A. S., Mohd Noor, M. A., Yusof, R., Yusof, H. "Kesahan model amalan kepimpinan guru [Teacher leadership model validity]". JuKu: Jurnal Kurikulum \& Pengajaran Asia Pasifik, vol.3 no.2, pp1-11.

[87] Rahayu, S. "Peningkatan Prestasi dan Proses Belajar Kimia Dasar Mahasiswa Bilingual melalui Strategi Team-based learning [Bilingual Student Achievement Improvement and Basic Chemistry Learning Process through Team-based Learning Strategy]". Jurnal Cakrawala Pendidikan, vol.3 no.3. https://doi.org/10.21831/cp.v3i3.1623 (Retrieved 24 June 2020).

[88] Tang, K. N., See, C. M. "Special Education Teacher
Leadership Practice: A Malaysian Study." International Journal of the Humanities, vol.7 no.3.

[89] Davies, B., Brighouse, T. (Eds.). "Passionate leadership in education." Sage, 2008.

[90] Tan, A. L., Ooi, S. Y., Teh, H. L. "Lesson Study: Amalan Kolaboratif Untuk Pembelajaran Berkesan di Institut Pendidikan Guru [Collaborative Practices for Effective Learning at the Institute of Teacher Education]." International Seminar on Generating Through Research, UUM-UMSIDA.

http://dx.doi.org/10.21070/picecrs.v1i1.571 (Retrieved 24 July 2020).

[91] Zetty, N. R., Siti Rashidah A. R., Norshilawni, S., Ahmad Shafiq, M. R, Zanaton, H. I., Sri Andayani, M. Y. "Strategi Pengajaran Guru Pendidikan Islam Mengintegrasikan Ilmu Naqli dan Aqli Menggunakan Pendekatan 'Lesson Study' [Islamic Education Teacher Teaching Strategies Integrate Naqli and Aqli Knowledge Using the 'Lesson Study' Approach]". Sultan Alauddin Sulaiman Shah Journal, vol.4 no.1, pp162-174. http://journal.kuis.edu.my/jsass/images/fil es6/jsass_vol4bil1_016_zetty.pdf (Retrieved 24 July 2020). 